\title{
DOES THE COVID-19 PANDEMIC AFFECT FOOD SAFETY TRAINING OF FOOD SECTOR EMPLOYEES? CASE STUDY
}

doi: 10.2478/czoto-2021-0021

Date of submission of the article to the Editor: 06/12/2020

Date of acceptance of the article by the Editor: 30/03/2021

\author{
Szymon T. Dziuba ${ }^{1}$ - orcid id: 0000-0002-6509-5843 \\ Anna Ulewicz ${ }^{2}$ \\ ${ }^{1}$ Wroclaw University of Economics, Poland \\ ${ }^{2}$ Medical University of Silesia/Czestochowa University of Technology, Poland
}

\begin{abstract}
Food health safety has always been an important element for consumers. Enterprises in the food sector want to meet customer expectations and the requirements set out in national and international legislation and implement a variety of tools, methods, or techniques in their organizations. Increasing health safety and even improving the quality of produced food is possible through properly planned training of employees. This training should be tailored to the capabilities and needs of both employees and the enterprise. Nowadays, with the era of the COVID -19 pandemic, training in food safety becomes of particular importance, as the production of safe food is a basic objective to be taken into account by all employees. Under these circumstances, it seems appropriate to carry out additional training in the prevention of the spread of COVID-19 in the context of the health safety of the produced food. The aim of the present paper is to examine the subjective assessment of food employees regarding the amount and quality of food safety training in the COVID-19 pandemic. The research is a pilot study conducted at the turn of December 2020.
\end{abstract}

Keywords: food safety, training, COVID-19

\section{INTRODUCTION}

Whether a company succeeds depends to a large extent on its employees, their training, level of competence, and capability of creative thinking. It was P.F. Drucker (1964) who emphasized the importance of four classic management functions, especially personal development, noting that it should be given priority in every organization. Science points to the relationship between these problems and factors such as education, training, and staff development. According to Zbiegień-Maciagg (1996), employee development means improvement, i.e. promoting entrepreneurship, innovativeness, identification with the enterprise, or broadening intellectual horizons, but also the acquisition of values, culture, and a person's own initiative.

Stankiewicz-Mróz (2007) noted that an important tool for employee development is training, i.e. a planned process of learning, with its aim being to develop the competencies needed to perform both current tasks and those planned in the future. 
Kopertyńska (1991) treats training as teaching employees (through their participation in various courses) the technical methods to perform activities at their workstations. Pocztowski (1998) formulated his views in a similar way by emphasizing that vocational training means any intentional and structured activities of the enterprise aimed at deepening or broadening individual elements of the work potential and at the development of new skills in employees as a response to the current and future needs of the enterprise.

However, as emphasized by M. Juchnowicz and T. Rostowski (2002), the involvement of five entities (termed the training quintet) is necessary for the training to produce the expected results:

- senior managers, preparing the organizational strategy, training strategy, and project budget,

- line manager, who identifies training needs in the subordinate unit and participates in the evaluation of training results,

- training manager, who reviews the training needs and chooses the institution or people to carry out the training and controls the training as a whole,

- coach, who prepares and conducts the training program,

- employees undergoing training: reporting development needs and evaluating training effectiveness.

It is important to treat training as a process consisting of certain stages, from the identification of training needs to the improvement of training while taking into account the needs of employees and the organization. The concept presented by R.W. Griffin (2004) is schematically presented in Fig. 1.

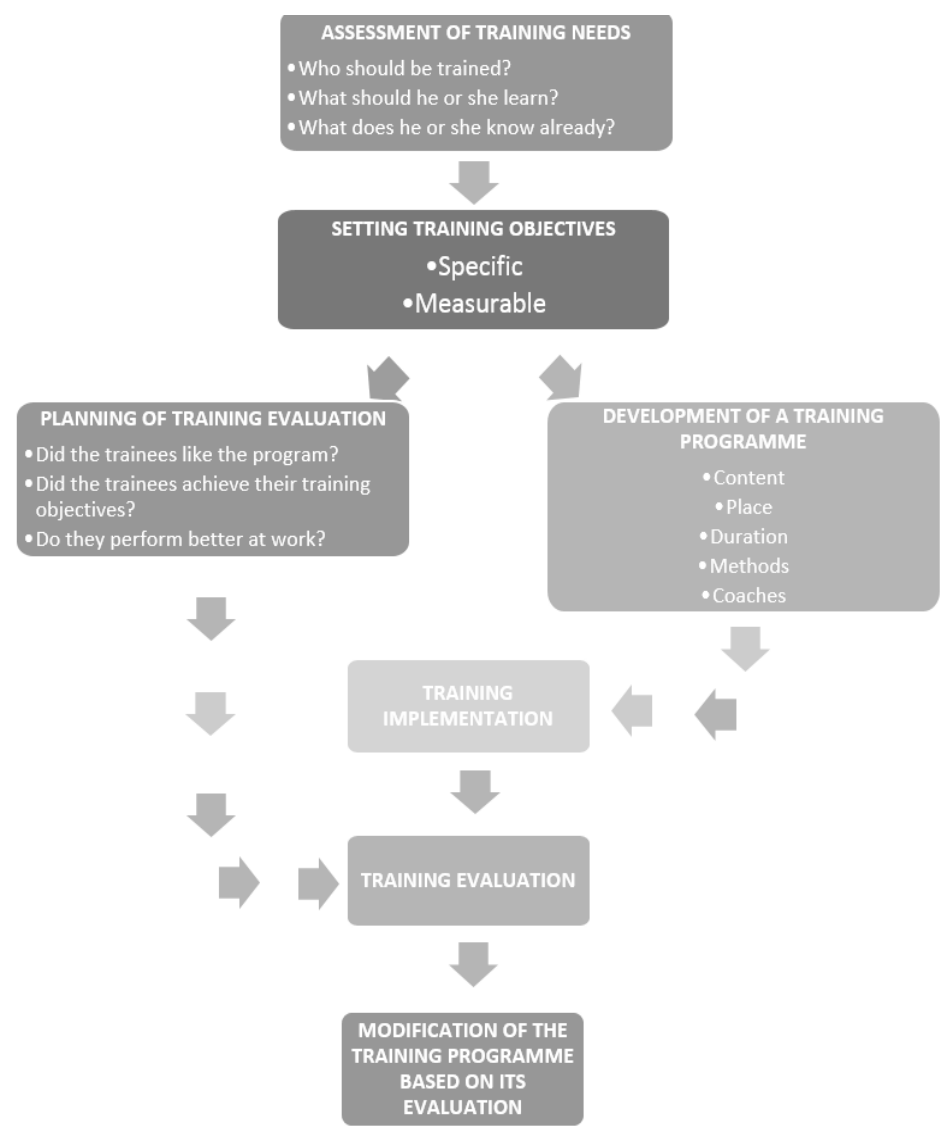

Source: (Griffin, 2004)

Fig. 1. Training process in the organization 
Each of the elements shown in Fig. 1 is extremely important. However, special attention should be paid to the choice of training methods. Okon (2004) argues that training methods were systematized neither in teaching nor psychological sciences. However, this researcher proposed one of the easiest methods of dividing them by distinguishing between involuntary and intentional learning, and, using another division, learning in parts and as a whole. Furthermore, Piwowar-Sulej (2019) notes that there are many divisions of training methods, but the most basic division is into on-the-job and off-thejob methods. These concepts were discussed in more detail by Sokół (2002), who emphasized that on-the-job training consists in transferring the necessary knowledge, developing skills and behaviors needed for specific jobs occupied by employees. This type of training allows for the acquisition of skills that the employee can use while performing their duties. This type of training is also called work-based training. The method is undoubtedly particularly useful for new employees. However, it is also used in the case of people already employed to retrain them or modify their job description if needed. Examples of such training include (Czerniachowicz, 2010; Dziuba and Ingaldi, 2017):

- vocational training,

- assistantship,

- replacement,

- multilateral leadership,

- instructions,

- quality circle,

- learning centre.

With regard to off-the-job training (performed outside the workplace, in isolation from work), their essential feature is that the practical use of knowledge and contents is only made after a given training. Examples of such initiatives include (Czerniachowicz, 2010; Rosak-Szyrocka and Abbase, 2020; Kielesińska and Pristavka, 2019):

- seminars,

- lectures,

- conferences,

- case studies,

- planning games,

- role-playing,

- simulations.

When choosing a training method (on-the-job or off-the-job), it is important to remember to see both their advantages and disadvantages (see Fig. 2). 


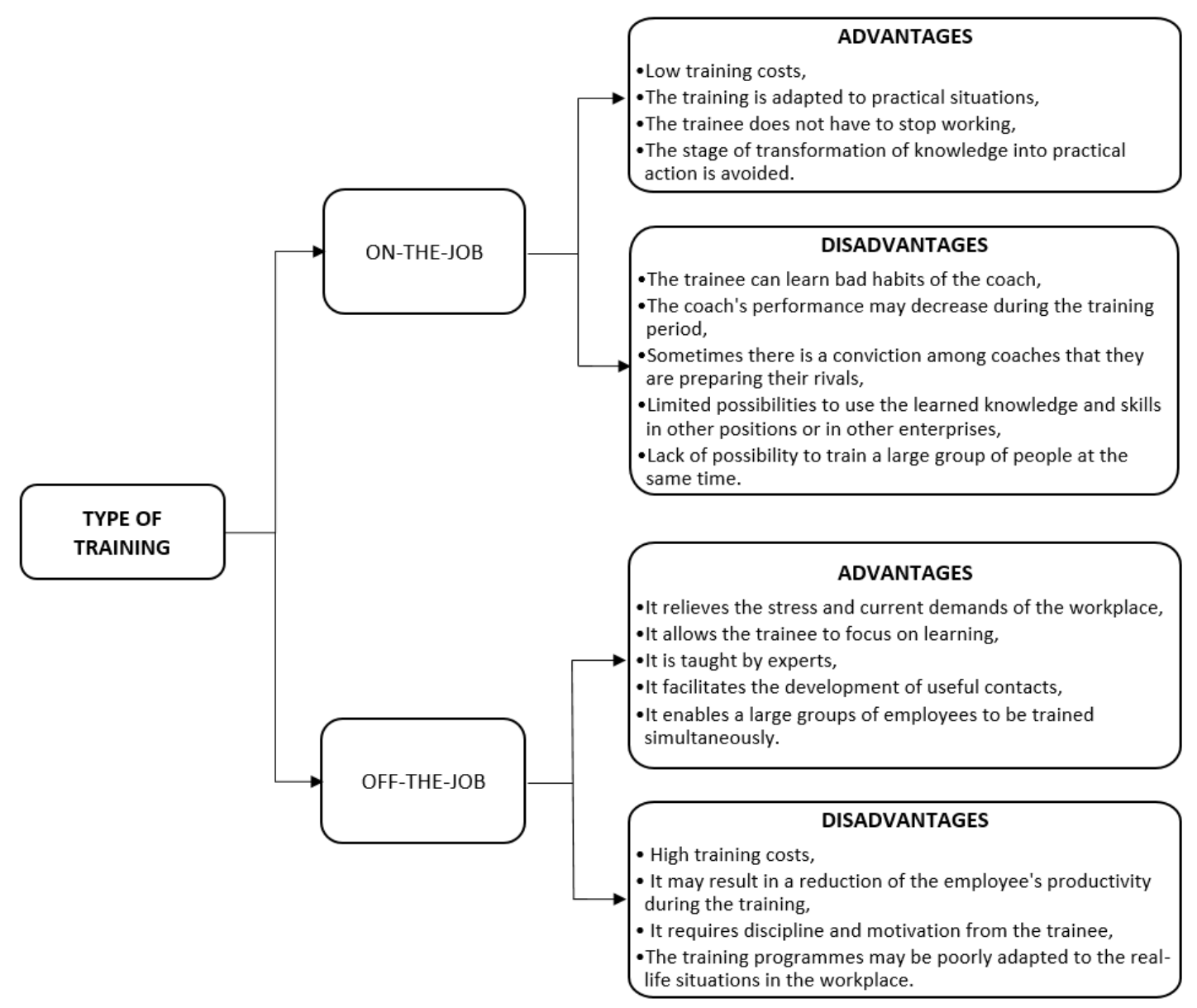

Fig. 2. Training process in the organization

Source: (own study based on Czerniachowicz, 2010)

The contents shown in Fig. 2 should certainly be taken into account in the food sector by the managers who make decisions on employee training in enterprises of the sector. This issue has already been emphasized by such authors as Acikel et al. (2008), Bolton et al. (2008), Capunzo et al. (2005), and Cenci-Goga et al. (2005), who argued that the participation of food sector employees in training contributes to the improvement of their qualifications, including personal hygiene. Staff training should be carried out according to a strict timetable. Furthermore, as stressed by Medeiros et al. (2011) their contents should include food quality, personal hygiene, the basics of microbiology, and the training itself should comply with international guidelines and standards used in the food industry. Each training should have a clearly specified purpose, program, and scope, and follow a specific scheme to assess its usefulness and effectiveness (KlimeckaTatar and Ingaldi, 2020).

\section{FOOD SAFETY TRAINING DURING THE COVID-19 PANDEMIC}

With the COVID-19 pandemic, the effective operation of the food supply chain is a fundamental objective for all parties involved, as it is essential to maintain both consumer trust and their confidence in the safety and availability of food (COVID-19 $\mathrm{i}$ bezpieczeństwo żywności - wytyczne dla przedsiębiorstw sektora spożywczego).

According to the latest WHO reports (Coronavirus disease 2019 (COVID-19) Situation Report) and based on currently available evidence it can be concluded that COVID-19 transmission occurs primarily during close contact with other people: the virus can be 
transmitted directly from person to person if a person infected with COVID-19 coughs or sneezes and emits droplets that penetrate the nose, mouth or eyes of another person. Therefore, the transmission is possible via infection carriers, i.e. from human to human (Liu et al., 2020; World Health Organization. Report of the WHO- China Joint Mission on Coronavirus Disease 2019). However, it should be noted that COVID-19 infection via food or its packaging is highly unlikely. To date, there is no scientific evidence to suggest that respiratory disease viruses, including COVID-19, are transmitted through food or food packaging. Researchers claim that coronaviruses cannot multiply in food. To do this, they need a host (an animal or a human). Nevertheless, attention should be paid to the results of the most recent research which evaluated the survival of COVID-19 on different surfaces. It was demonstrated that coronavirus can survive up to 72 hours on plastic or stainless steel surfaces, up to 4 hours on copper and up to 24 hours on cardboard surfaces. However, it must be taken into account that these analyses were carried out under laboratory conditions (by controlling relative humidity and temperature) and therefore care should be taken to interpret these results in a real environment (van Doremalen et al., 2020; Kis et al., 2020). In the context of the results of all these studies, it should be stressed that it is extremely important for the food industry to improve the personal hygiene regime, but also, perhaps most importantly, to carry out training courses that promote food hygiene rules in order to eliminate or reduce the risk of contamination of the food surface or its packaging with a virus transmitted by employees. Food safety management systems (FSMS) come to support these initiatives in the food industry, implemented according to the principles of Hazard Analysis and Critical Control Points (HACCP) to manage risks to food safety and prevent food contamination. These systems are implemented using prerequisite programmes that consist of good hygiene practices, cleaning, disinfection, delimitation of production zones, control of suppliers, storage, distribution and transport, staff hygiene and staff ability to work, and thus all the basic conditions and activities needed to maintain a hygienic food processing environment.

In this context, the management of each food enterprise plays an extraordinary role. The most important tasks of the representatives of this level include (Szkiel, 2013):

- identification of the necessary competences of staff whose activities have the greatest impact on food safety,

- organization of training or taking other measures to ensure that staff has the necessary competences mentioned in the previous item,

- ensuring that staff responsible for monitoring and corrective actions within the food safety management system is systematically trained,

- emphasizing that staff is aware of the nature and importance of their individual actions in ensuring food safety,

- care for effective communication, understood by all personnel whose actions have an effect on food safety,

- ensuring adequate training records.

The measures discussed must include, in particular, training of each worker who comes into direct contact with food at each stage of food processing, production, and marketing chains. Training in times of a pandemic should be treated in a special way: it should be properly planned and prepared, bearing in mind that, according to the principle of continuous development, the improvement must include not only new employees but also those already employed. It should also be remembered that training is a continuous 
process, whereas formal instruction and management of this process significantly improves its effectiveness. If the training programme is well-thought-out and properly implemented, it will benefit both the organization and its employees and, above all, consumers (Ingaldi and Klimecka-Tatar, 2020; Baryshnikova et al., 2020).

\section{METHODS AND AIM OF THE STUDY}

As demonstrated by the studies presented in the previous part of this study, published by both Polish and foreign authors, the health safety of the produced food is a key factor. This is confirmed by the content of the current legislation, as it includes all the requirements and procedures necessary to ensure the proper quality of food and nutrition. According to the current law in force both in Poland and in the European Union, food that is dangerous to health even to the lowest level is not allowed for consumption. It should be remembered that taking care of quality and, above all, food safety requires careful control and, importantly, self-control of employees. Such actions are only effective if an appropriate training program in this area is developed and implemented. This means, first and foremost, the focus on ensuring adequate conditions for the production of food of the expected quality and an appropriate level of safety for the consumer. When planning the scope of topics learned during training, it is also important to take into account the aspect of constant awareness of specific risks and, if they occur, the rules of conduct.

Currently, the COVID-19 pandemic is such a threat. Therefore, the combination of the pandemic with employee training concerning the safety of the food they produce is a very important topic that represents a research gap. The employee perspective provided by the assessment of training conducted during the pandemic by individual employees seems to be extremely important. The aim of the present paper was therefore to examine the subjective assessment of food employees regarding the number and quality of food safety training in the COVID-19 pandemic. The research is a pilot research and represents a case study.

\section{RESULTS}

The empirical research was carried out by means of a questionnaire interview using a five-stage Likert scale. The reason for this choice was to refer to the opinion by Kubik (2014), who argued that the questionnaires are designed to collect opinions and information on the effect of training on the work performed. The questionnaires can be used to collect feedback following the training, to collect data to assess the contents of the training programme, or to examine the effect of the training on the work in the enterprise.

The survey was carried out at the turn of December 2020 among the employees of enterprises that produce food in the Lower Silesia Voivodeship. The survey was attended by 28 people from various industries. Catering activities were the most frequent $(75 \%)$, followed by entities involved in the processing of fruit and vegetables and other foodstuffs ( $11 \%$ each), whereas $3 \%$ were representatives of the meat processing industry. The results are presented graphically in Fig. 3. 


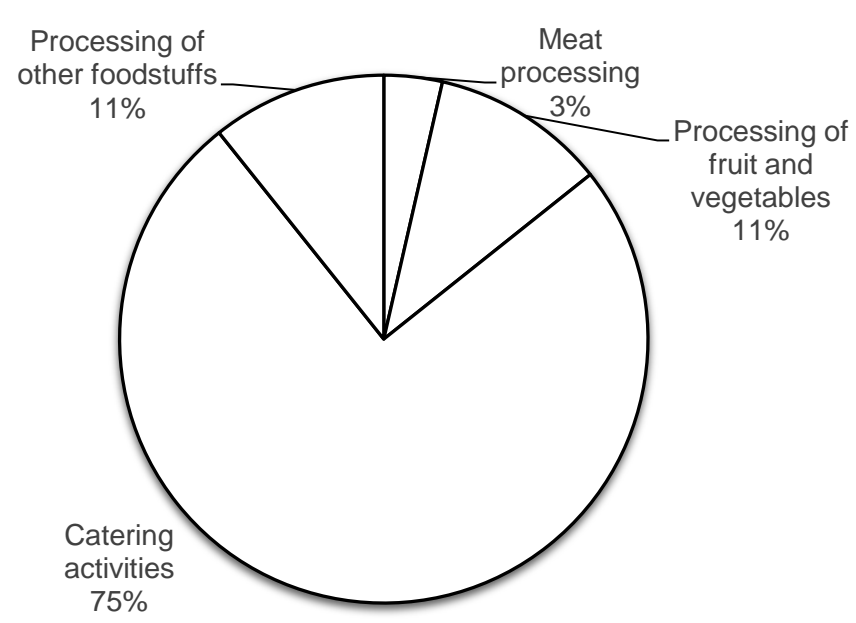

Source: own study

Fig. 3. Respondents by industry

Of the 28 people who filled out the questionnaire correctly, women were the most represented group (57.1\%). Furthermore, taking into account the level of education of employees, it should be noted that the largest group were people with secondary education (67.9\%), while in terms of age, the largest group were employees under 25 years of age $(85.7 \%)$.

Table 1

Characteristics of the social structure of respondents

\begin{tabular}{|c|c|}
\hline Sex & Percentage [\%] \\
\hline Woman & 57.1 \\
\hline Man & 42.9 \\
\hline Age (years) & Percentage [\%] \\
\hline Under 25 & 85.7 \\
\hline $25-29$ & 10.7 \\
\hline $30-34$ & 0 \\
\hline $35-39$ & 3.6 \\
\hline $40-45$ & 0 \\
\hline Over 46 & 0 \\
\hline Education & Percentage [\%] \\
\hline primary & 0 \\
\hline vocational & 67.9 \\
\hline secondary & 32.1 \\
\hline higher & Percentage [\%] \\
\hline Job seniority (years) & 53.6 \\
\hline Up to a year & 46.4 \\
\hline Over a year up to five years & 0 \\
\hline Over five years up to ten years & 0 \\
\hline Over ten years & \\
\hline
\end{tabular}

Source: own study

Analysis of the data on job seniority presented in Tab. 1 reveals that an insignificant majority of people had worked in the enterprises for less than a year (53.6\%). Other respondents worked from one year up to five years. It can therefore be assumed that employees with such job seniority should have extensive knowledge of the health and 
safety of food production. Nevertheless, in times of a pandemic, training in this field is much needed, if not essential, for all age groups, regardless of how long employees have been working in the enterprise.

In the first place, the respondents were asked whether their enterprise provides employees with an increased level of knowledge about the safety of the produced food. The distribution of the answers is presented in Fig. 4.

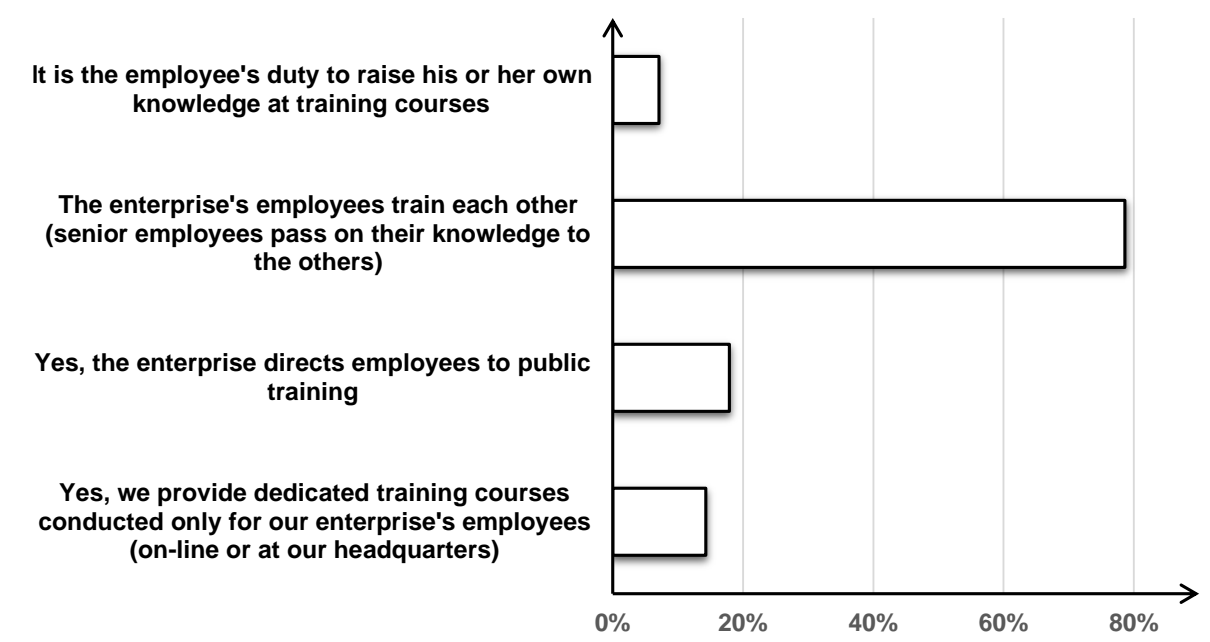

Fig. 4. Distribution of the respondents' answers to the question of ensuring that employees raise their level of knowledge about the safety of the food they produce Source: own study

The data presented in Figure 4 show that only $14.3 \%$ of the employees are directed to special training in food safety, whereas $17.9 \%$ participate in training on this subject, but this is not a one-issue training. Interestingly, as indicated by $78.6 \%$ of the respondents, training in food safety is carried out using the on-the-job system by other trained employees in the enterprise.

In the next question, the employees were asked what type of training was organized in their enterprise to train workers in the health safety of the food they produce. The answers collected are illustrated in the chart presented in Fig. 5.

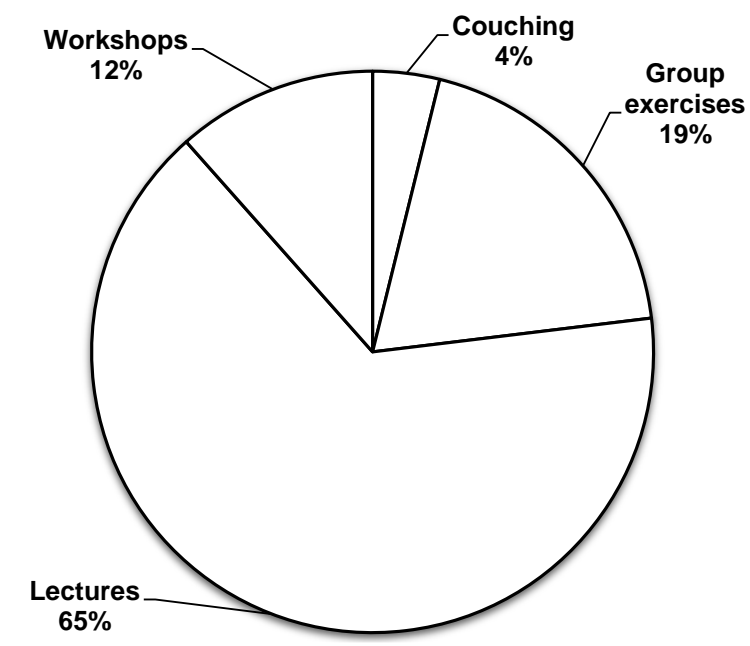

Fig. 5. Type of training organized in the enterprise to train employees in the health safety of the food they produce

Source: own study 
As results from the data presented in Fig. 5, in order to train employees in terms of taking care of the safety of the food they produce, lectures are most often organized $(70 \%)$, followed by group exercises $(16 \%)$, then workshops $(11 \%)$, while coaching is the least frequent form of training in food safety.

In view of the COVID-19 pandemic, the questionnaire asked the respondents to answer the question of whether training in the health safety of produced food taking into account the current epidemic situation was conducted in their enterprises, (either at the enterprise's headquarters or on-line). The answers are presented in Fig. 6.

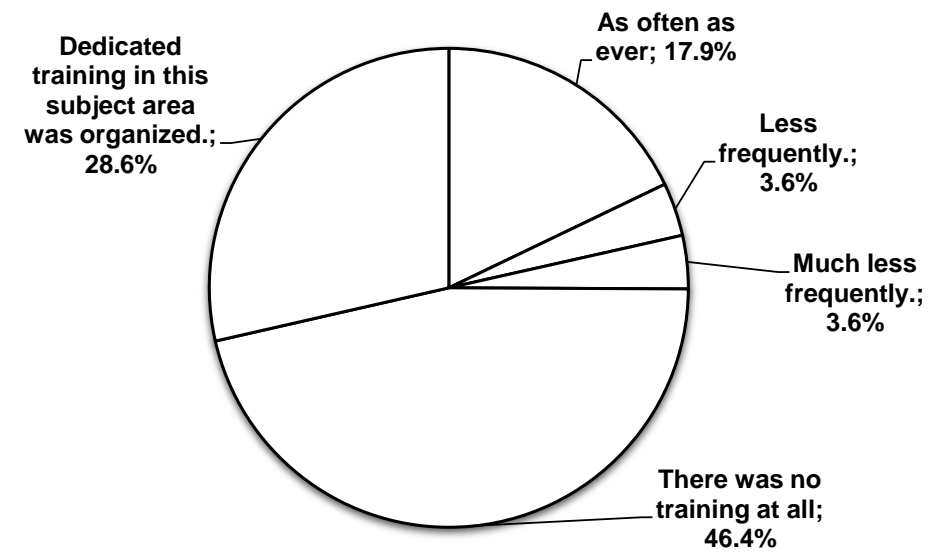

Fig. 6. Number of training courses (either in the enterprise's headquarters or on-line) on the health safety of produced food after the COVID-19 pandemic was declared (March 2020)

Source: own study

As shown in Figure 6, the respondents indicated that as much as $46.4 \%$ of enterprises did not organize food safety training after the pandemic was declared. Only $28.6 \%$ of the enterprises organized additional special training concerning the pandemic in the context of health safety of produced food. Furthermore, $17.9 \%$ of the respondents stated that the training courses were held according to the schedule, at the same frequency as before the outbreak of the pandemic. It is worrying that despite the pandemic, training in this area was less frequent or much less frequent (3.6\% each). The last issue raised in the survey was the staff assessment of the latest food safety training provided. The results based on the answers are presented in Fig. 7. 


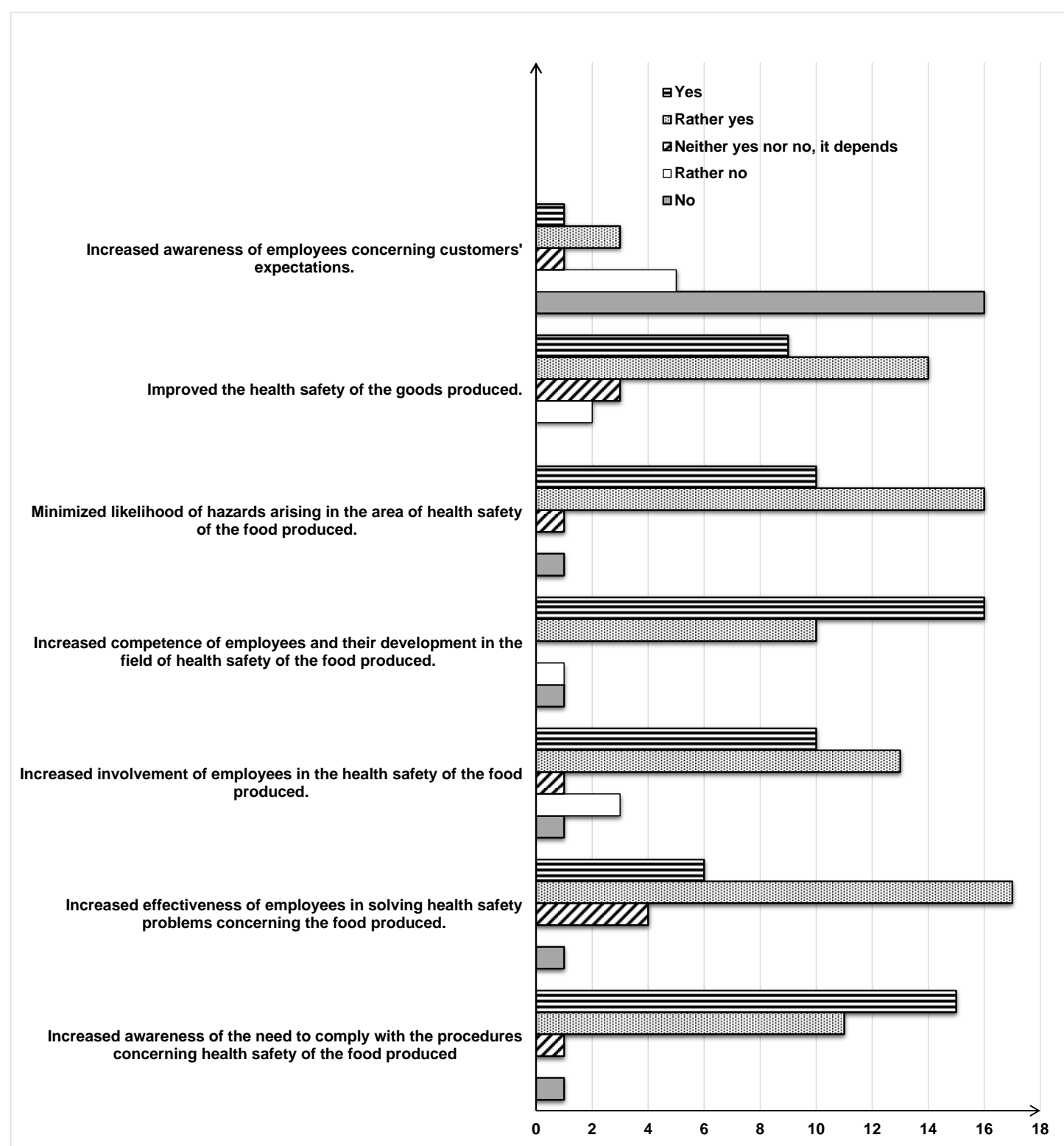

Source: own study

Fig. 7. Assessment of food safety training by employees

Analysis of the distribution of the answers presented in Fig. 7 reveals that in the opinion of the respondents, the training results in an increase in awareness of the need to follow procedures that increase the health safety of the produced food, increase the effectiveness of employees in solving related problems, their greater involvement in the health safety of the produced food, increase their competence and their development in terms of taking care of the health safety of the produced food. Undoubtedly, these training courses also translate into minimizing the likelihood of hazards. Furthermore, the research shows that, according to the employees, the training does not result in an increased awareness of customers' expectations in this area.

\section{CONCLUSIONS}

With an efficient food control system, the food industry, both Polish and global, is constantly subject to processes of evolution and improvement. This is a particularly important aspect during the current pandemic, as food should be free of any hazards. 
In their elimination, training is of great importance. Staff training and improvement programmes should always be adapted to the circumstances in the enterprise. The managers in food enterprises should constantly verify that their training and development activities are delivering the results expected as this leads to the improvement in consumer safety. Nowadays, the pandemic has changed the reality of life in many areas, including food safety training. Particular care should be taken that food employees are prepared for the changes that will take place in enterprises during and after the COVID-19 pandemic. It is necessary to teach them how to act in different situations, especially when symptoms of the disease appear. It is necessary to develop procedures in situations where employees become ill. In the circumstances of a pandemic, managers should ensure that food safety standards are respected through, among other things, training, as only people who know what food safety and quality are can be aware of the importance of these factors and can be involved in their promotion in the enterprise. The new circumstances surrounding the COVID-19 virus mean that risks must be minimized. An integral part of the new reality should therefore be the training which will not only improve employees' skills and competencies but will also change their attitudes and awareness of food safety. Therefore, training objectives should result from both the company's strategy and the identified gap in the desired and existing competence profiles of individual employees in the area of food safety. Training should take into account different contexts, heterogeneous groups of participants, and their different skills, as the participants usually differ in terms of age, work experience, qualifications, education, or skills, as presented in the research described in the present paper.

\section{REFERENCES}

Acikel, C.H., Ogur, R., Yaren, H., Gocgeldi, E., Ucar, M., Kir, T., 2008. The hygiene training of food handlers at a teaching hospital, Food Control., 2008, 19(2), 186-190.

Baryshnikova, N., Kiriliuk, O., Klimecka-Tatar, D. 2020. Management approach on food export expansion in the conditions of limited internal demand, Polish Journal of Management Studies, 21(2), 101-114. DOI: 10.17512/pjms.2020.21.2.08

Bolton, D.J., Meally, A., Blair, I.S., McDowell, D.A., Cowan, C., 2008. Food safety knowledge of head chefs and catering managers in Ireland, Food Control, 19(3), 291-300.

Capunzo, M., Cavallo, P., Boccia, G., Brunetti, L., Buonomo, R., Mazza, G., 2005. Food hygiene on merchant ships: the importance of food handlers' training, Food Control, 16(2), 183-188.

Cenci-Goga, B.T., Ortenzi, R., Bartocci, E., Oliveira, C.A., Clementi, F., Vizzani, A., 2005. Effect of the implementation of HACCP on the microbiological quality of meals at a university restaurant, Foodborne Pathogens and Disease, 2(2), 138-145.

Coronavirus disease 2019 (COVID-19) Situation Report - 66, Available on: https://www.who.int/docs/default- source/coronaviruse/situation-reports/20200326sitrep-66-covid-19.pdf?sfvrsn=81b94e61_2, (access: 10.12.2020).

COVID-19 i bezpieczeństwo żywności - wytyczne dla przedsiębiorstw sektora spożywczego, Available on: https://www.gov.pl/attachment/8fd44000-8d15-44b88952-a0050412d4c7, (access: 10.12.2020).

Czerniachowicz, B., 2010. Rola szkoleń w rozwoju kapitału ludzkiego w przedsiębiorstwie, Zeszyty Naukowe Uniwersytetu Szczecińskiego. Studia i Prace Wydziału Nauk Ekonomicznych i Zarządzania, Szczecin, 17. 
Drucker, P.F., 1954. The practice of management, Harper \& Brothers, New York.

Dziuba, S.T., Ingaldi, M. 2017. Systems Providing Food Safety and its Perception by Polish Customers - Introduction, 17th International Multidisciplinary Scientific GeoConference, 2017, Vol. 17. Ecology, Economics, Education and Legislation. Iss.53. Environmental Economics, STEF92 Technology Ltd., Sofia, 835-842.

Griffin, R.W., 2004. Podstawy zarządzania organizacjami, Wydawnictwo Naukowe PWN, Warszawa.

Huang, C.L., Wang, Y.M., Li, X.W., Ren, L.L., Zhao, J.P., Hu, Y., Zhang, L., Fan, G.H., Xu, J.Y., Gu, X.Y., Cheng, Z.S., Yu, T., Xia, J.A., Wei, Y,. Wu, W.J., Xie, X.L., Yin, W., Li, H., Liu, M., Xiao, Y., Gao, H., Guo, L., Xie, J.G., Wang, G.F., Jiang, R.M., Gao, Z.C., Jin, Q., Wang, J.W., Cao, B., 2020. Clinical features of patients infected with 2019 novel coronavirus in Wuhan, China, Lancet, 395, 497-506.

Ingaldi, M., Klimecka-Tatar, D., 2020. People's Attitude to Energy from Hydrogen - from the Point of View of Modern Energy Technologies and Social Responsibility, Energies, 13(24), 6495. DOI: 10.3390/en13246495

Juchnowicz, M., Rostowski, T., 2002. Podglądanie konkurencji, czyli jak korzystać z raportów o wynagrodzeniach, Warszawa 2002, Personel i Zarządzanie, 21, 26-33.

Kielesińska, A., Pristavka, M., 2019. Maintaining the Appropriate Level of Quality in the Aspect of Machinery and Equipment Safety in Food Industry, Conference Quality Production Improvement - CQPI, 1(1), 124-130. DOI: 10.2478/cqpi-2019-0017

Kis, S., Mosora, L., Mosora, Y., Yatsiuk, O., Malynovska, G., Pobihun, S., 2020. Personnel Certification as a Necessary Condition for Enterprise' Staff Development, Management Systems in Production Engineering 28(2), 121-126. DOI 10.2478/mspe-2020-0018

Klimecka-Tatar, D., Ingaldi, M., 2020. How to indicate the areas for improvement in service process - the Knowledge Management and Value Stream Mapping as the crucial elements of the business approach, Revista Gestão \& Tecnologia, 20(2), 5274.

Kopertyńska, W., 1999. Działalność przedsiębiorstw w zakresie rozwoju potencjału pracy zatrudnionych, [in:] Tokarski S. (eds.) Skutki restrukturyzacji i prywatyzacji przedsiębiorstw w Polsce $w$ dekadzie lat dziewięćdziesiątych, Zeszyty Naukowe Uniwersytetu Gdańskiego, 13.

Kubik, K., 2014. Doskonalenie i rozwój pracowników globalnych organizacji, Zeszyty Naukowe Uniwersytetu Przyrodniczo-Humanistycznego w Siedlcach, Seria: Administracja i Zarządzanie, 29(102), 63-77.

Liu, J.Y., Liao, X.J., Qian, S., Yuan, J., Wang, Yingxia Liu, Y.X., Wang, Z.Q., Wang, F.S., Liu, L., Zhang, Z. 2020. Community transmission of severe acute respiratory syndrome coronavirus 2, Shenz, Chin, 2020, Emerging Infectious Diseases, 26(6), 1320-1323. DOI: 10.3201/eid2606.200239

Medeiros, O.C., Barletto-Cavalli, S., Salay, E., Proença, C.P.R., 2011. Assessment of the methodological strategies adopted by food safety training programmes for food service workers, Food Control, 22(8).

Okoń, W., 2004. Wprowadzenie do dydaktyki ogólnej, Wydawnictwo Akademickie Żak, Warszawa.

Piwowar-Sulej, K., 2019. Profesjonalne zarządzanie szkoleniami w organizacjach, Wydawnictwo Uniwersytetu Ekonomicznego we Wrocławiu, Wrocław.

Pocztowski, A., 1998. Zarządzanie zasobami ludzkimi. Zarys problematyki i metod, Antykwa, Kraków. 
Rosak-Szyrocka, J., Abbase A.A. 2020. Quality management and safety of food in HACCP system aspect, Production Engineering Archives, 26(2), 50-53. DOI: 10.30657/pea.2020.26.11

Sokół, B., 2002. Szkolenie i rozwój pracowników, [in:] Gołaszewska-Kaczan, U. (eds.), Proces kadrowy w przedsiębiorstwie, Wydawnictwo Uniwersytetu w Białymstoku, Białystok 2002.

Stankiewicz-Mróz, A., 2007. Ocenianie i rozwój pracowników, [in:] Jędryck, E. (eds.), Zarządzanie zasobami ludzkimi dla menadżerów średniego szczebla, Wydawnictwo Wolters Kluwer Polska, Kraków.

Szkiel, A., 2013. Projektowanie systemu zarządzania bezpieczeństwem żywności z wykorzystaniem zasad zarządzania jakością, Prace Naukowe Wałbrzyskiej Wyższej Szkoły Zarządzania i Przedsiębiorczości, 25(5), Inżynieria innowacji: zarządzanie operacyjne $w$ teorii i praktyce organizacji biznesowych, publicznych i pozarządowych, 385-406.

van Doremalen, N., Bushmaker, T., Morris, D.H., Holbrook, M.G., Gamble, A., Williamson, B.N., Tamin, A., Harcourt, J.L., Thornburg, N.J., Gerber, S.I., LloydSmith, J.O., de Wit, E., Munster, V.J., 2020. Aerosol and surface stability of SARSCoV-2 as compared with SARS-CoV-1, The New England Journal of Medicine, 382, 1564-1567. DOI: 10.1056/NEJMc2004973

World Health Organization. Report of the WHO-China Joint Mission on Coronavirus Disease 2019 (COVID-19), 16-24, February 2020, Geneva 2020. Available on: https://www.who.int/docs/default- source/coronaviruse/who-china-joint-mission-oncovid-19-final-report.pdf, (access: 10.12.2020).

Zbiegień-Maciąg, L., 1996. Marketing personalny, czyli jak zarządzać pracownikiem w firmie, Wydawnictwo Businesss Press, Warszawa. 